\title{
The Comparison of Financial Analysis Tools in Conventional and Islamic Banking: Evidence from Kuwait
}

\author{
Farooq Alani ${ }^{1}$, Hisham Yaacob ${ }^{1} \&$ Mahani Hamdan ${ }^{1}$ \\ ${ }^{1}$ Dept. of Accounting and Finance, FBEPS, University of Brunei Darussalam, Brunei \\ Correspondence: Farooq Alani, University of Brunei Darussalam, Brunei. Tel: 673-246-3001. E-mail: \\ farooq.alani@ubd.edu.bn
}

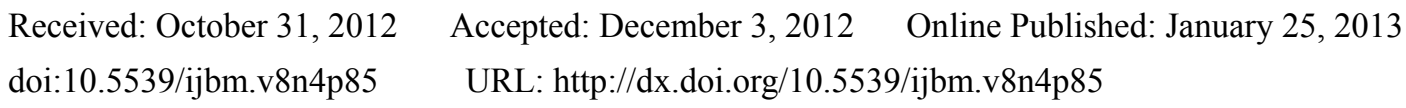

\begin{abstract}
The research presents a study of the efficiency of financial analysis tools used in Islamic banks and the efficiency of achieved results to investor in his rationalization of investment decisions, the researcher studied that by using a questionnaire search tool which included three axes, the study find several conclusions, perhaps the most important of the current analysis used in traditional banks are irrelevant in assessing the efficiency of the financial performance of Islamic banks because of their privacy.

The researcher presents many recommendations, most notably, he urged researchers to focus on formulation of new analysis tools with focusing on Islamic banks, and also the researcher has developed a number of tools that can serve in this field.

The researcher presents a number of recommendations and proposed a financial analysis for Islamic banks, traditional banks, financial analysis and investment decisions.
\end{abstract}

Keywords: efficiency, financial analysis tools, Islam banks, conventional banks

\section{Introduction}

Financial analysis is one of the important financial tools in business organisations. It is part of decision making processes used by financial managers to make financial decisions and for planning and control. The managers identify potential financial problems and analyse the effects of alternative courses of action prior to making a decision, whereas financial analysts use tools of financial analysis to recommend the best alternatives. There are various tools of financial analysis such as ratio analysis, trend analysis, benchmarking and balanced scorecard, and it is impossible to say which tool is the best.

Most financial analysis tools are targeted toward external reporting and applied according to the situation. Financial managers choose between several tools of financial analysis to help them evaluate the market and investing in a way so as to maximize the profit from the investments made. They select the financial analysis tools by making reference to the goals and methods of investments used and types of information needed related to specific organisations. Considering that the tools are developed and designed to meet different investment purposes, users cannot apply similar tools in all aspects of investment to make analysis.

In a banking sector, even though both traditional and Islamic banks utilise similar tools of financial analysis, not many of the tools provide relevant information to investors in Islamic banks which have great concern for privacy and confidentiality. Different from traditional banks, all financial transactions in Islamic banks are interest-free, trade-based and asset-linked (Hidayat and Abduh, 2012). Few studies showed that religious beliefs are not customers' sole reason to select an Islamic bank, but the product features (Sharia compliance) and service quality including ethics, privacy and confidentiality whilst transacting with Islamic banks (Alani and Alani, 2012; Awan and Bukhari, 2011). It is on this basis that researchers of this study made an assumption that Islamic banks requires a specific and appropriate analysis tool which can provide more relevant information for making investment decision.

Researchers further argue that financial analysis tools of traditional banks do not fully serve investment decision makers in Islamic banks. Whether the analysis tools in traditional banks assist and provide better guidance to investors in Islamic banks to make decisions, it is yet to be investigated. 
Hence, the objectives of the study are to identify the financial analysis tools used in Islamic banks irrespective of the privacy concerns; highlight the shortcomings of the analysis tools; determine if there is a difference in the investment methods between Islamic and traditional banks; and finally assess the extent of usefulness of the financial analysis tools in Islamic banks in making investment decisions.

This paper is structured in the following order.

\section{Literature Review on Financial Analysis}

\subsection{Definition}

Financial analysis began to take the lead in business when finance operated independently as an important area in an organisation in 1900. Finance as a separate unit or function came into existence following the results of field studies in financial analysis on 981 companies through seven financial ratios in the United States. The studies reported the overall financial situation of the companies. Ever since, financial analysts' job becomes a profession and represents the core function of financial unit and development. They are highly marketable and their qualifications are globally recognized by professional accountancy bodies. Financial analysis, as part of financial management, is also now taught in many universities and institutes (Al Sayah and Ameri, 2007).

Khanfer and Matarna (2006) refers financial analysis to the procedural process of accounting information system designed to provide information from the published financial statements and other non-financial information, in order to help the beneficiaries to make their economic decisions. Matar (2003), on the other hand, defines it as a process by which to explore or derive a set of qualitative and quantitative indicators on project activity economic contribute in determining the importance and properties of operating activities, and the project's financial statement through the extracted information from the financial statements and other sources to use these indicators in evaluating the company's performance in order to make decisions. In this study, researchers describe financial analysis as a mathematical model used to analyse the figures reported in the published financial statements, in order to provide information for making decisions and help evaluating the performance of companies and the companies' ability to continue to operate indefinitely ('going concern').

Based on the above definitions, researchers arrive at the following conclusions. Firstly, published financial statement is the basis of financial analysis activities. Analysts set off doing the analysis after accountants finished their work, so we must understand the foundations and components of these financial statements before we analyze it. Secondly, beneficiaries and financial analysts must be able to use analysis tools study these financial statements and find relationships between elements of these financial statements to get to the financial value of the project at a certain date. They must be able to provide and decipher internal and external information about their performance, profitability and ability to continue in the future.

\subsection{Types}

Qyasa (2006) identifies two types of financial analysis: analysis according to financial ratios and analysis according to quantity tactics. The first type of analysis relates to identification of what percentage intended (\%) on the relationship between two variables or items that share common characteristics or similar conditions, and finding the relationship between two percentages or variables that accountants have common characteristics to study.

The second type of analysis uses quantitative methods. It was applied in the second half of the last century as a result of evolution of financial function in employment field and financial decision-making. The method analyzes the phenomena or an activity carried out by facilities, identifies the relationships between variables that control and directs activities and takes decisions to organise the activities (Qyasa, 2006, p. 22). Qyasa indicated that graphs can be used in making the analysis. The method (which also known the mathematical method) is as well applied to study various economic changes and results of the analysis are published according to a way to serve the purpose of planning and control (Matar, 2003).

The evolution of financial analysis is attributable to many factors, most notably of which is the shifting business structure model, from individual and private companies to public or joint stock companies. The expansion of company activities and development both in vertical and horizontal positions, the growth of mergers' operations, expansion and new developments of investment products and the internal and external business and economic growths. All these led to the advances in financial analysis field, with taking into consideration the pace of economic, social and cultural developments, and the development in accounting information systems (Al Sayah and Ameri, 2007, p. 48). Moreover, financial analysis has become an integral part of administrative, economic and financial decision-making (Saeed, 1982).

As the roles of accounting and finance evolve, the scope or objectives of financial analysis have also increased as 
follows:

1) To identify the strengths and weaknesses of unit performance and serve information from various perspectives for deep insights to users who have financial interest in the unit.

2) To assess the profitability and credit risk in the financial statements to check the adequacy of funding, managing the assets and liabilities, financial position of the unit, and the ability to continue operations.

3) To develop some indicators that point to suitable management tools for planning, monitoring and evaluation of performance (Matar, 2003, p.3).

4) To examine unit's ability to repay obligations through the studies of relationship between assets and liabilities and the ability of those assets to cover liabilities during a certain period (Hayali, 2004, p. 22). Results from the analysis are used as a means to correct possible deviations and evaluate unit performance (Salam, 2008, p. 449).

5) To provide information to financial institutions and lenders on the possibility of granting loans to a unit or an organisation, through economic indicators related to the unit's ability to fulfill its economic obligations towards them (Melicher and Norton, 2005).

\subsection{Requirements}

A set of requirements or conditions which represent the basic components of financial analysis, has been formulated to achieve these objectives. Since financial analysis involves making predictions about the future, analysts' activities must be flexible, comprehensive, cost saving and are worth the effort. Outputs from the analysis have to be achieved and reported instantaneously to avoid the information from becoming obsolete (Al Sayah and Ameri, 2003, p. 50). Sources of the analysis must have a reasonable degree of credibility or reliability, objectivity and relevance.

Financial analysts must also be able to use scientific approaches (Hayali, 2004, p. 23), commensurate with analysis process and the balance between substantive and appropriate goals. The roles of analysts include identifying the strengths and weaknesses of unit performance, diagnosing the causes and effects of financial situations and extrapolating future trends (Gibson, 2009). They must have good knowledge about the internal and external conditions of a unit before doing data analysis and disclose the basis of their interpretations from the important factors and data that being studied. Analysts must avoid bias in the interpretations of their report analysis and present suitable indicators, recommendations and better alternatives to decision makers (Matar, 2003, p. 5).

\subsection{Beneficiaries}

Naimi et al. (2007) clustered two beneficiary groups of financial analysis: internal and external beneficiaries. Internal beneficiaries are those who reside and work directly within an organisation such as directors, shareholders (investors) and employees in the organisation. External beneficiaries are those who are indirectly affected in some way from the decisions made comprising suppliers, lenders, banks, competitors, businessmen, insurance companies, labour unions, researchers and scholars, state and society.

Abbas (2008, p. 71-72) categorised them into four groups as follows:

1) Shareholders - those who care aspects related to the ability of a financial manager to achieve profits on their investments, the financial situation of the company and profitability ratios that can be used.

2) Company directors - evaluate their operational efficiency that concerns all financial ratios in the extraction and interpretation of results, identify its strengths and weaknesses, address deviations and improve performance.

3) Short-term debt owners - they seek to ascertain if the company was able to meet current financial obligations in due date, means attention to liquidity.

4) Long-term debt owners - creditors are sometimes required to verify their company's ability to meet debt installments and interest payments in their maturity dates, so they focus on ratios that help them to predict the company's ability to achieve earnings and long-term liquidity.

In view of the diverse classifications of beneficiaries, researchers here suggest for financial indicators to be divided into two sets of analysis. One is to meet the needs of internal beneficiaries who utilize information for evaluation and correction of deviations to achieve business goals, make predictions of the future financial position and address financial shortage problems. The other is to meet the needs of external beneficiaries who analyze published financial statements to ascertain the company's ability to fulfill present and future obligations 
and contracts concluded, and as well make financial and investment decisions.

\subsection{Process}

The scientific method of financial analysis starts by first determining the purpose, goal or objective of the analysis and directly relates data to the analysis objective. As each goal entails specific data, analysts with their technical skills will select appropriate analysis tools to get best results and some indicators to predict the future. Once the analysis is done, analysts will arrive at several conclusions and recommendations.

Overall, the process of financial analysis can be presented in three stages: preparation, analysis and conclusions and recommendations (Khanfar and Matarna, 2006, p. 77). The following explains each of the stages.

1) Preparation stage - this stage begins after analyst receives a designation letter from either external or internal parties to conduct a financial analysis of the company. Good preparation will have positive impact on the implementation of the analysis and outputs. This stage includes goal-setting, determines the extent and scope of the analysis, and identification and collection of information and data necessary for analysis.

2) Analysis stage - Analysts in this stage process available data to serve the analysis goals. The task includes classification and reclassification of information, choosing appropriate tool for analysis and identify deviations.

3) Conclusions and recommendations stage (report writing) - This is the final stage of financial analysis. It reaps out information from the previous steps. Analysts in this stage are expected to develop conclusions, suggestions and solutions based on facts characterized by simplicity, clarity and conciseness.

In this study, the researchers posit that understanding of the steps or process of financial analysis will lead to rationalization of administrative decisions in investments field by evaluating a bank's financial performance using analysis tools.

\subsection{Standard}

Standard is a tool measured by specific things in order to give a particular provision and interpretation of results (Hayali, 2004, p. 98). The standards used in financial analysis are as follows:

1) Absolute standards (typical) - are fixed standards based on experiments and field studies. Agreement of using this standard is reached between units. For example, financial analysts to compare the proportion of trading extracted from the financial statements of 3:1 with an agreed absolute standard of 2: 1 (Alsayah and Ameri, 2007, p. 54).

2) Historical standards - are based on past economic results reflected from previous financial statements and performance. Financial analysts in this case compare the current results of the financial situation with past performance results using time periods or variables as panel data, and then interpret and give judgement of the overall position (Kieso, Kimmet and Weygandt, 2000, p. 673).

3) Sectorial standards (industrial) - are standards that derive from comparative results among units in similar sectors. There are also indicators agreed by these units to be viewed as standards (Kieso et al., 2000, p. 673).

4) Targeted standards (situation) - are standards based on future plans of a company. Analysts study the actual or achieved results compared to the plan and consider the application of targeted standards for future financial planning (Naimi et al., 2007, p. 102).

To sum up, these standards of financial analysis prove to be beneficial for evaluating financial performances, wherein analysts can make comparisons between actual and previous performances, and between actual and expected performances (Al Sayah and Ameri, 2007, p. 54). Some banks use historical standards to compare the results of their annual performances to track the progress of their performances and the stability of their financial position. Central banks and other banks may employ certain proportions or indicators to assess liquidity (cash) and profitability and measure them against these standards. Some organisations apply standard costing to estimate the budgets of their financial items and compare it between actual and budgeted expenses or income and evaluate variances (Al Shamai and Khalid, 1990).

\subsection{Usefulness}

Tools of financial analysis function as keys to measure performance, creditworthiness, investment returns and effects of financial performance pre and post mergers and acquisitions.

1) Performance analysis - this analysis is important for internal users of a company's management. They use financial information available in the financial statements and financial data to make analysis for control, 
planning and performance evaluation purposes. Ratios include turnover rates, investments, inventory and turnover of net working capital and assets (Matar, 2003, p. 23).

2) Credit analysis - this analysis seeks to identify potential risks or dangers faced by lenders in their relationships with borrowers. Short and long-term credits are assessed to obtain information on a unit's ability to meet the debt and benefit payment when due, financial policies, the effects on the capital structure of the unit, the objectivity of evaluating assets provided as collateral and debt/bankruptcy risk if the unit went into liquidation or financial distress (Saeed, 1982). Useful indicators in this analysis are short-term liquidity indicators, financial leverage indicators or long-time solvency and long and short term cash flow.

3) Investment analysis - this analysis is important for investors (current and potential shareholders) who are interested in current and future company's resources and their ability to continue, investment growth rates, market risks and the efficiency of unit management in terms of financial policies and exploitation of economic resources (Matar, 2003, p. 22). Quantitative indicators are useful in this analysis such as profitability ratios, market risk and other indicators.

4) Mergers and acquisition analysis - this serves to evaluate a unit's business performance intending to merge with or purchase other business units. It is based on an appropriate method, followed by the merging company to pay for shares of the merged companies (subsidiaries) and explore the potential effects of the merger at pre and post merger/acquisition (Qyasa, 2006, p. 304).

\subsection{Approaches}

Researchers identify two approaches of financial analysis: traditional and modern methods.

In a traditional method, financial analysts use financial ratios for the purpose of analysis and judgment on a company's activities (Alsayah and Ameri, 2007, p. 52). They use a comparative analysis that is a complement to the traditional method, to compare between current and previous data or with standard or industry indicators (Hayali, 2004, p. 117).

Modern method (quantitative) helps to achieve more accurate results. It is time and cost savings approach for analysts as the work is largely computerized. Analytical programme is designed and prepared to treat many problems faced by economic units through storage and processing of information and emergence of outputs (Alsayah and Ameri, 2003, p. 52). The programme is branched out into statistical and mathematical methods. The statistical method is based on a standard figure (Note 1) and time series of a group of data set for a number of years. Financial analysis using this standard figure is called horizontal time series (which preferably does not exceed a five-year time series as to ensure the accuracy and consider the non-economic impact on value inflation of the items involved in the analysis process). Mathematical method is represented by changing programs, data method and linear programming (Hayali, 2004, p. 129-135).

Matar (2003) highlights the importance of qualitative approach in financial analysis. The author argued that evaluating the numbers on the published financial statements alone are not adequate to arrive at conclusions because quantitative data are not the only outcome of accounting policies that determine the type and nature of the accounting principles and methods. Financial analysts must extend their range of study from examining the quantitative data to qualitative explanations of the published data. This includes specific features of unit profitability and financial position.

Qualitative approach is valuable in banking sector or industry for two reasons. Firstly, the largest part of the bank's assets and liabilities falls within cash category. There is a need to assess risks associated with it including the risk of volatility, purchasing power of cash unit that arises in periods dominated by high rates of inflation and exchange price risks arising from volatility in foreign exchange rates. Secondly, the largest part of banks' assets is financed by other sources which make liquidity and solvency influential indicators than other types of economic indicators. Positive capital adequacy is important to attain favourable capital structure leverage.

Qualitative indicators found in banks' financial statement analysis are comprised of the following.

1) The type and nature of accounting policies used in the recognition of income and expenses, especially those related to commissions and interest received as the main source of revenues. The type and nature of credit policies adopted in granting loans and facilities, and the impact of these policies on the classification of loans portfolio. Non-performing loans proportion in the portfolio and policies in dealing with these loans.

2) Strategy in the management of the investment portfolio of the bank and the nature of risks surround them. The type and nature of assets provided as collateral for loans and facilities and the fair values of those assets.

3) The accuracy and objectivity of the methods used in assets and liabilities evaluation. Its compatibility with 
the rules laid down in the principles or accepted accounting standards in general. Also, the extent and nature of contingent liabilities of pledges made by the bank to customers and others.

Hayali (2004, p.138) mentioned that qualitative analysis is a way to convert data to get a structured information for decision making. Data analysis and classification is an important element of the knowledge representation. The model explains the analyst's perception when estimatingthe possible solutions for real-world problems in the case of incorrect or incomplete data. Such analysis is considered as an important element for financial analysis. The financial analysis does not stop at just reading and explaining the existing relations between numbers in the financial statements. In banks the purpose of the qualitative analysis is to get complete knowledge to ensure that investment process is stable and strengthened.

Alabed (2006, p.47) identifies two model types that apply qualitative analysis.

1) Balanced scorecard: A tool in strategic management to help business units to translate company's strategy into standard accurate measure of performance. It helps to integrate the various sections in the company and work in parallel to achieve the desired results. Robert Kaplan and David Norton argued (the idea of this system in 1992) the system can achieves a balance between short and long term strategic goals through strategic maps which is the focal point of the balanced scorecard.

2) CAMELS model: An efficient way to evaluate banks performance and determine the strength and durability of the financial position. Its ability to deal with any variables or developments related to activity to identify strengths and weaknesses points in banks performance. It enhances the capabilities of the regulatory authorities. The system elements are capital adequacy, asset quality, management quality, earning, and liquidity and then added a sixth element in 1997 which is sensitivity of market risks (Sinkey and F, 1998). All of these elements are expressed with a number of financial indicators.

The study found that most of the banks are not doing this qualitative analysis. They stopped at analyzing the financial ratios and added assessment of banks' performance. Central banks confirm that qualitative indicators can add value to the results obtained from the financial ratios analysis

\section{Bank Performance}

Performance means the degree or level of skill or effort made in implementation and intended output or objectives system seeks to achieve (Salam, 2008, p.245). We can define performance evaluation as comparing results (Jomaa, 2000, p.44). This definition clarifies two matters: (1) Measures the achievement or planned goals, means evaluate goals; (2) the extent of appropriate and efficient method used to achieve goals (efficient performance) (Zayoud, 2005, p.166).

For banking performance, financial performance is one of the important indicators that measures the company's ability to achieve its goals (Aqil, 2000, p.279). Banking performance means comparing the targets with the achieved results (Taha, 2003, p.26). The necessary tools and various activities run by the banks to meet the goals (Salam, 2008, p.245). So the banking performance is vivid portraits reflectingthe bank's ability to achieve objectives according to suitable standards. The commercial banks are considered as one of the important financial institutions.

Financial performance will stay as the only measure for banks success (Walther et al., 1997, p.66). Eccles (1991, p. 134) considers the trends towards measuring the performance of banks in accordance with the financial perspective in more sophisticated approaches. The development in financial performance field guarantees a competitive advantage to the bank towards strengthening and development of the banks. There are various fields which bank seeks to measure and every one of them reflects the target a bank seeks to achieve. Table 1 shows the stakeholder groups and performance metrics that indicate goals and interests. 
Table 1. Stakeholder groups and their influence on organization performance

\begin{tabular}{|c|c|c|}
\hline Class & Performance measurement in short term & Performance measurement in long term \\
\hline \multirow[t]{3}{*}{ Consumers } & Sales (value and volume) & Growth in sales \\
\hline & New consumers & Turnover consumers \\
\hline & $\begin{array}{l}\text { The number of new consumer needs that are } \\
\text { provided }\end{array}$ & The ability to control prices \\
\hline \multirow[t]{5}{*}{ Suppliers } & The cost of raw material & Growth rates in each of \\
\hline & Delivery time & The cost of raw materials \\
\hline & Stock & Delivery time \\
\hline & Providing raw material & Stock \\
\hline & & New ideas processors \\
\hline \multirow{4}{*}{$\begin{array}{l}\text { Financial } \\
\text { community }\end{array}$} & Revenue on stock & \multirow{4}{*}{$\begin{array}{l}\text { The ability to convince the stock market } \\
\text { strategy adopted } \\
\text { Growth in yield to the right of ownership }\end{array}$} \\
\hline & The market value of share & \\
\hline & $\begin{array}{l}\text { The number of lists that recommends buying } \\
\text { organization shares }\end{array}$ & \\
\hline & Yield to the right of ownership & \\
\hline \multirow[t]{3}{*}{ Individuals } & He number of proposals & The number of promotions from inside \\
\hline & Productivity & Turnover rate \\
\hline & Number of complaints & \\
\hline \multirow[t]{2}{*}{ Legislature } & $\begin{array}{l}\text { Number of new legislation affecting the } \\
\text { organization }\end{array}$ & $\begin{array}{l}\text { He number of new laws that affect the } \\
\text { industry }\end{array}$ \\
\hline & Relations with the members and crew & $\begin{array}{l}\text { The level of cooperation in the } \\
\text { competitive confrontations }\end{array}$ \\
\hline \multirow{4}{*}{$\begin{array}{l}\text { Consumer } \\
\text { protection } \\
\text { agencies }\end{array}$} & Number of meetings & Change in policy times \\
\hline & Number of unfriendly confrontations & Due to the pressure bodies \\
\hline & Number of coalition formation & Claims of assistance by bodies \\
\hline & Number of cases & \\
\hline \multirow{5}{*}{$\begin{array}{l}\text { Advocates } \\
\text { for the } \\
\text { environment }\end{array}$} & Number of meetings & \multirow{5}{*}{$\begin{array}{l}\text { Number of claims assistance by } \\
\text { defenders of the environment }\end{array}$} \\
\hline & Number of unfriendly confrontations & \\
\hline & Coalition formation & \\
\hline & Number of complaints to the specialized agencies & \\
\hline & Number of cases & \\
\hline
\end{tabular}

Source: (Cetro and Peter, 1995, p.146)

There are various methods for evaluating banks performance and perhaps the most important and most frequently used is quantitative method.

\subsection{Ratios}

Ratios are popular in the second half of the last century as a result of evolution in financial functions in financial decision-making. Quantitative method is a technique that uses quantitative phenomena analysis. It studies the relationships between variables in the activities of companies and decision-making such as investment and loan portfolios (Hanawi et al., 2009, p.48).

There is also accounting information system designed to provide information from published financial and non-financial statements to help beneficiaries to make economic decisions (Khanfar and Matarna, 2006). The bank credit is used as a measurement to assess the financial performance of banks customers who seeks credit facilities (Taha, 2007). Under this approach the scope of the financial analysis will be limited in the quantitative 
aspect of the phenomenon under study and analysis (Matar, 2003).

The most common quantitative methods used:

\section{a- Financial ratios analysis}

The financial ratios is considered the most important tools and most prevalent among financial analysts. It is one of the oldest tools which appeared in the mid-nineteenth century used to make economic decisions. Khanfar and Matarna (2006) argued that financial ratios as the most important tools in financial analysis to help the administration to know (1) the liquidity of the bank; (2) the position of available money for lending; (3) the suitability of property rights and profitability of the bank (Ziad and Mahfouz, 2003).

We can express financial ratios in various forms; as a percentage break rate and in a way which the ratio depends on the specific needs of those who will use the available information. Many of the ratios can be calculated from the financial statements. Therefore, financial analysis using percentage aims to determine the criteria to evaluate performance of the bank. So the ratios do not mean anything to the reader unless it is compared to standard values or other ratios (Al Shamai and Khalid, 1990).

To determine the optimal financial ratios that can be used in banks financial analysis, we must realize the differences. In views of the commercial banks performance which can be only two goals, first profitability and second growth as a strategic goal bank seeks to achieve through profitability goal. Any development and expansion achieved by banks over time. Al Maidani (1989) makes a connection between rates of growth in the economy and growth in the natural economic units. If the growth of the unit is less than economy it means stagnant and if it is higher than the economic growth so it make development and expansion. We can determine the relationship between growth and profitability through financial statements of the bank and the cash flow (Al Hindi, 2000). Alshamai and Amen identify most common financial ratios in measuring financial performance of the bank as follows:

1) Profitability: include (the rate of return on property right, the rate of return on investment, profit margin, and return on total money employment for lending).

2) Growth: include (asset growth rate, multiple property right, and property retention rate).

3) Liquidity: measuring the ratio of cash to average demand deposits, and cash ratio to average total deposits, and the average cash and short-term investments to total deposits and demand deposits.

4) Durability or capital property adequacy (capital adequacy): the ratio is measured equity to total assets and the ratio of capital to deposits or to total assets and risky assets or loans and commitment.

Alhindi presents the ratios which are commonly used in banking sector (Al Hindi, 1990):

1) Liquidity ratios

2) Profitability ratios

3) Capital adequacy ratios

4) Lending financial aid.

\section{b- Leverage analysis}

This analysis consisted of three leverages (operating leverage, financial leverage, and common leverage). Operational leverage describes the cost structure of the bank, the financial leverage describes the funding side of the bank and common leverage is a study of the common leverage effects. Matar connects this analysis to a point at the height of any of them will necessarily lead to the lifting of equally point and vice versa. Thus, impacts on the risk that will respond consistently with proportional ascending and descending in the relationship (Matar, 2003). Therefore, the goal of measuring the leverage is to know the degree of risk surrounding the bank.

\subsection{Islamic Banking}

The following table's shows banks and financial institutions spread in six geographic regions prepared by the international union of the Islamic banks. 
Table 2. Geographic distribution of Islamic banks

\begin{tabular}{llcc}
\hline & Region & Total paid-up capital (\$'000) & Total assets (\$\$000) \\
\hline $1-$ & States of Gulf Cooperation council federation & 1357612 & 18489200 \\
2- & Middle East countries & 2228037 & 34210162 \\
3- & European and U.S. countries & 226123 & 386471 \\
4- & Southeast countries & 121214 & 1575488 \\
5- & South Asian countries & 126858 & 3866840 \\
6- & African countries & 4954007 & 101125873 \\
& total & 4954007 & 101125873 \\
\hline
\end{tabular}

Source: Islamic Development Bank - Jeddah

There are multiple definitions for Islamic banks, (Al Najar, 1980) defines it as:

"Islamic bank is an institution to collect money and employ them according to Islamic law in order to serve the solidarity of Islamic society, achieve fair distribution, and putting money in Islamic path"

The study proposes that the Islamic bank is a financial institution working to attract the cash resources of community members with good employment according to Islamic law and within the established rules of Islamic law also to serve nation people to develop their economies.

The Central Bank of Kuwait defines the Islamic Banks in accordance with article 82, "Islamic Banks are banks work in banking profession in accordance with the provisions of Islamic law), in addition to acts like opening accounts also have different operations according legitimate contracts such as profitability, participation and speculation also direct and indirect investment that does not contradict with Islamic law and in accordance with regulations of central bank."

The study finds that the Islamic banks are financial institutions working to develop Muslim money according to Islamic law away from usurer with a social agenda by contributing in the social development.

\subsection{Hallmarks of Islamic Banks}

Islamic banks have certain characteristic and attributes. It presents banking services in a different manner on the basis of dealing with religion and credit. The Islamic banks do not deal with usurer in whatever forms. So the relationship between the customer and the Islamic banks are like participation and trading and they may take speculative trading form, participation, profitability in buying and selling (Alwadi \& Samhan, 2007).

The social role of the Islamic banks next to their economic role, such as collection and distribution of Zakat, good loans and contribute to social projects. Alsuwehi determined the following points which represent the difference between traditional and Islamic banks (Ghafar and Abu Kahaf, 2000, p.19):

1) Objectives

2) Relationship between the bank and customers

3) Diversification of investment activities

4) Relationship with the Central Bank

5) The way of accounting depositors

6) Control over the banks activity

7) Commercial bank cares in insurance

8) The Islamic bank prevents to invest in contrary projects to Islamic law, such as pork and gambling.

9) Commercial bank concentrates most funds employment in secure portfolio while Islamic banks' participation in that portfolio is very limited.

10) Commercial bank can issue preferred shares while Islamic bank cannot.

11) In Islamic banks there are two accounts for investment: public investment account established according to absolute speculation rules and the other one in accordance to restricting speculative rules in specific projects.

12) General reserve in commercial banks is deducted from the net profit, while in Islamic banks, the reserve is deducted from the net profit for shareholders. 


\subsection{Money Uses in Islamic Banks}

Alsawan determined money uses in Islamic banks as follows (Al Sawan, 2008, p.135):

1) Speculation

2) Participation

3) Sale profitability

4) Trades

5) Sell to order

6) Leasing or rent

7) Consumers sale

8) Manufacturing

9) Agricultural and irrigation

\section{Methodology}

The study used descriptive analytical to find ways to harmonize financial analysis in investment decisions in Islamic banks. This approach is known as a systematic explanation to describe a phenomenon or specific problem quantitatively by collecting data and codified information (Molhem, 2010).

\subsection{Samples}

The study determined the companies and investment agencies that deal with portfolio management in Kuwait and registered in Central Bank of Kuwait. The number of companies was 14 and these companies are registered in the stock market of Kuwait. They manage portfolios and making decisions on for investment decisions. Two companies were selected from the 14 companies specialized in portfolio management on random basis. They are (1) Global; (2) KMEFIC. They are leaders in this field, and transacted most of the specialized investment. They also have experts in portfolio management, financial and technical analysis accompanying the investment process.

\subsection{Data Collection}

Data was collected using questionnaire. The questionnaire was distributed to 20 employees in the two companies. About 10 percent of the employees in each company specialized in financial analysis of the banking sector. They also have the power and authority to make investment decisions through direct management of investment portfolio or by reference to the owners of portfolios. In addition to this, some interviews were conducted with the sample of both companies. Secondary data are derived from Islamic finance books and periodicals.

\section{Results}

The questionnaire has three axes and the results were statistically analyzed as follows:

The first axis is trying to measure the appropriate tools of financial analysis for Islamic banks, and whether it serves the investment decision makers. The general standard explained a statistically significant difference in the financial analysis tools used in traditional banks do not serve investment decision makers in Islamic banks. The hypothesis were accepted at $95 \%$ which supports the presence of a statistically significant difference in the trends of the importance and role of the financial analysis used in traditional banks that does not serve investment decision makers in Islamic banks. Annex (2).

The second axis explained that Islamic banks differ from traditional banks by the statistical differences between Islamic and traditional banks in the financial analysis tools and risk measurement, were accepted moral imposition by $95 \%$ which prevail a statistical difference in the direction and consensus that there are already differences between Islamic and traditional banks in the financial analysis tools and risks (Annex 3).

The third axis measures the effectiveness of financial analysis ratios for investment decision makers in Islamic banks. The general index explained the existence of statistical difference, and Islamic banks require privacy and a special kind of financial analysis in which if applied it will give more appropriate information for making investment decisions. The hypothesis was accepted by $95 \%$ who strongly supports the difference existence in attitudes and opinions that Islamic banks require special financial analysis tools. The standard was divided into two important parts, the first confirm that the tools used does not fit Islamic banks, and the second emphasizes the need for a change and development in the analytical tools used to serve Islamic banks. (Annex 4). 


\section{Results and hypothesis:}

By reference to research hypothesis and the results obtained have shown the following:

1) A great importance of financial analysis tools in the process of investment decision makers as explained in first and third standards.

2) The third standard results confirmed the first hypothesis, where the tools in existence form cannot serve the investment decision maker in Islamic banks for being sufficient information that will help rationalization in decision maker.

3) The second hypothesis had been confirmed through the results of the second standard, which confirmed that Islamic banks have privacy through risk and work mechanisms, and require that the financial analysis tools used is to serve the investment decisions.

\section{Discussion}

\section{A proposal for financial Islamic tools can be used in Islamic banks:}

Proposal for analytical tools that fit Islamic banks:

The study attempts to draw attention on the importance of this matter. Islamic banks have affected our economies and the industry is on a steady growth. These Islamic banks differ from the traditional banks in both the quality of products and without any interest (money generating money) or through the principle of solidarity between the client and the bank through induction faceted investment allowance for faceted aspects. As well as through social and developmental role beside profit that comes in second place.

Traditional banks consider liquidity an improtant aspect, but most accounts owners and depositors are not linked to investment contract for participation and solidarity, rather take a form as a creditor of the bank. Therefore, haunted by the problem of liquidity, the banks face the possibility of money withdrawn every day from depositors. The Islamic bank is based on the participation and solidarity in this aspect, which in effect, the liquidity problem becomes less severe.

Islamic bank retains a portion of liquidity in the hands by means of investment. It does not offer conventional loans that make the bank the owner of money and share customer money management. Lliquidity ratio must take into consideration that it must take all those components in addition to the central reserve such as cash equivalents comprising cash plus foliate plus balances with the central bank and other banks plus international profits and deposits exchange. Other important thing is that semi-liquid money of traditional bank containing the debtor and there is a risk of non-payment and the debtors' money combination in Islamic banks are profit, rent, and manufacturing money.

\section{Profitability ratios}

The study finds that it is necessary to develop ratios that provide more information on the profitability of the Islamic banks. Profitability of every service that banks provide, for example profit ratio for total profit and other services that give better information for management to make decisions. Also, the levels of investment risk among different Islamic services have to be clear. The study also added another important matter about the profit ratio of the bank by comparing the interests (traditional bank profit) and market interest rates. This does not serve Islamic banks because Islamic products profit are completely and radically different so we need other criteria for comparison and admit the financial performance of the bank. Most of the profitability ratios simulate interests as a work basis of traditional banks and this does not commensurate with the nature of the Islamic banks.

\section{Solvency ratio}

The ratios were highlighted in the Basel 2, and all these percentage about loans as essential products to traditional banks. It is hard to find a match in the Islamic banks because of the different nature of products and the risks associated with these products. So the study believes that ratios could be developed to be more appropriate for Islamic banks. Solvency ratios are to protect depositors and their money from loss due to mismanagement of the banks by giving loans that could not be covered. On the other hand, the Islamic bank is based on the participation and solidarity to lower of risk ratio. A new risk emerges in Islamic banks is market risk. The Islamic bank as a trader face market risks like other traders.

\section{Money employment ratios}

It measures employment of bank funds in investments to reap profits rather than keeping in safety stores. Most traditional bank investments are deposits and a small portion of them are investments. While Islamic bank 
investments is based on participation, so we must separate each of these tools and measure their usefulness individually, with an emphasis on the creation of standards for comparison. It should be different than those used by traditional bank because it would be futile and simulate the market interest rates also other tools like a rate of profit and others. Islamic banks do not work on rent principal that some of the assets if paid the full rent it will shift ownership and will be out of records when calculating Islamic banks' assets.

\section{Conclusion and Recommendations}

The study concludes:

1) The Islamic banks earnings processes are not consistent with traditional banks and these need commensurable analytical tools.

2) Some financial tools are not compatible if used in Islamic banks, for example, the legal reserve ratio express about something for traditional banks because they are the basic guarantee for the customers, because the rest of the cash credit is for others.

3) There is a severe scarcity of writings, research and books on financial analysis of Islamic banks, most of the literature focused on traditional banks.

4) The study noted that there is a lack of integration between the Islamic banks.

The study gives several recommendations, possibly to serve Islamic banks and investment decision-makers in this sector:

1) Studies and research should be directed to the creation of special analysis tools to help Islamic banks.

2) Invitation to portfolio managers and practitioners to find analytical tools for investment decision-makers in the Islamic banking sector.

3) The Islamic banks to find a common ground to create and build practical tools

4) The study tries to synchronize the current financial ratios dealing with Islamic banking sector, but it is not successful.

5) The Islamic banks in the Middle East to learn from its counterparts in the South East Asia which has been successful in implementing Islamic banking such as Malaysia.

\section{References}

Abbas, A. (2008). Financial management (1st ed.). Dar Ithra, Amman, Jordan.

Abboud, S. (2008). Cost management in the banking activity. Beirut, Lebanon: Dar Al-Murtada Printing and Publishing.

Akl, M. M. (2000). Presented in the financial management and financial analysis. Future Publishing House, Amman, Jordan.

Al Maidani, M. A. E. (1989). Directors corporate Financing. King Fahd University of Petroleum and Minerals, Dhahran, Saudi Arabia .

Al Sawan, M. (2008). The basics of banking - banking study analysis (2nd ed.). Dar Wael, Amman, Jordan.

Al Sayah, A. S., \& Al Ameri, S. (2003). Financial management - the theoretical and practical. Dar Wael, Amman, Jordan.

Al Sayah, A. S., \& Al Ameri, S. (2007). Financial management (3rd ed.). Dar Wael, Amman, Jordan.

Al Shamai, K. A., \& Khalid, A. (1990). Financial analysis of banks. The Union of Arab Banks, Beirut, Lebanon.

Al Wadi, M. H., \& Samhan, H. M. (2007). Islamic banks - the theoretical basis and applications (1st ed.). Dar Almasira, Amman, Jordan.

Al-Abd, J. I. (2009). Financial management - financial analysis for new projects. Al Maktab Al Jamyi, Alexandria, Egypt.

Alani, F. S., \& Alani, H. K. (2012). The role of Islamic ethics in accounting environment. IOSR Journal of Business and Management, 2(1), 26-30.

Al-Naimi et al. (2007). Financial management theory and practice (3rd ed.). Dar Almasira, Amman, Jordan.

Al-Najjar, A. (1980). Islamic banks and their impact on the development of Islamic Economics. Journal of Modern Muslim, 24. 
Awan, H. M., \& Bukhari, K. S. (2011). Customer's criteria for selecting an Islamic bank: evidence from Pakistan. Journal of Islamic Marketing, 2(1), 14-27.

Certo, S., \& Peter. (1995). The strategic management process (3rd ed.). Irwin Publication.

Eccles, R. G. (1991). The performance measurement manifesto. Harvard Business Review, Harvard University, USA.

Ghaffar, H. A., \& Abu Kahaf, A. S. (2000). Bank management and its applications (1st ed.). Beirut, Lebanon: University Press.

Gibson, C. (2009). Financial reporting and analysis. South-Western Cengage Learning, Singapore.

Hanawi et al. (2009). Financial management analysis projects. Al Maktab Al Jamyi, Alexandria, Egypt.

Hayali, W. N. (2004). Financial analysis. Hanin Publishing House, Amman, Jordan.

Hidayat, S. E., \& Abduh, M. (2012). Does Financial Crisis Give Impacts on Bahrain Islamic Banking Performance? A panel regression analysis. International Journal of Economics \& Finance, 4(7), 79-87.

Hindi, M. I. (1996). Financial management contemporary analytical (3rd ed.). Al Maktab Al Arab, Alexandria, Egypt.

Hindi, M. I. (2000). Management of commercial banks -decision making (3rd ed.). Al Maktab Al Arab, Alexandria, Egypt.

Jomaa, S. F. (2000). Financial performance of business organizations and the current challenges. Mars Publishing House, Riyadh, Saudi Arabia.

Khanfar, M., \& Matarna, G. (2006). Analysis of financial statements the theoretical and practical (1st ed.). Dar Al Masira, Amman, Jordan.

Kieso, D., Kimmet, P., \& Weygandt, J. (2000). Financial Accounting. Wiley \& Sons, USA.

Matar, M. (2003). Financial and credit analysis - methods and tools and uses Process. Dar Wael Publication, Amman, Jordan.

Melicher, R. W., \& Norton, E. (2005). Finance introduction to institutions, investments and management. Wiley $\&$ Sons, USA.

Mohammed, M. S. (2010). Research methods in education and psychology. Dar March, Amman, Jordan.

Nahar, H. S., \& Yaacob, H. (2011). Accountability in the sacred context: The case of management, accounting and reporting of a Malaysian cash awqaf institution. Journal of Islamic Accounting and Business Research, 2(2), 87-113. http://dx.doi.org/10.1108/17590811111170520.

Qyasa, F. (2006). Understand financial reports in accounting and management (1st ed.). Aleppo Shuaa for publication and science.

Saeed, F. M. (1982). Aware of public finance. Riyadh, Saudi Arabia: Global Printing and Publishing.

Samhan, H. (2000). Islamic banking operations - accounting concept (3rd ed.). AL Shams Press, Amman, Jordan.

Sinkey, J., \& F. J. R. (1998). Commercial Bank Financial Management. Prentice Hall International, Inc.

Taha, T. (2003). Banks and administration information technology. Dar Al Jama Al Jadida, Alexandria, Egypt.

Taha, T. (2007). Banks and administration information technology. Dar Al Jama Al Jadida, Alexandria, Egypt.

Walther, T., Johansson, H., Dunleavy, J., \& Hjelm, E. (1997). Reinventing the CFO: Moving From Financial Management to Strategic Management. McGraw-Hill, New York.

Yaacob, H. (2012). Issues and challenges of shari'ah audit in Islamic financial institutions: a contemporary view. 3rd International Conference on Business and Economics Research, Bandung, Indonesia. Retrieved from http://www.internationalconference.com.my/proceeding/3rd_icber2012_proceeding/183_382_3rdICBER20 12_Proceeding_PG2669_2679.pdf

Zayoud, M. (2005). Evaluate the performance of banks using financial analysis tools - a field study of the Industrial Bank of Syria. Tishreen University Journal for Studies and Scientific Research - Science Series, 27(54).

Ziad, R., \& Mahfouz, J. (2003). Contemporary trends in the management of banks (2nd ed.). Wael, Jordan. 


\section{Appendix}

Appendix 1

First: identifiable information (descriptive)

1) Age 25-30 31-40 40 and above

2) Sex male female

3) Current job title

4) Years of experience

\begin{tabular}{lllll}
\hline Less than 5 years & $5-10$ & $10-15$ & $15-20$ & Above 20 years \\
\hline
\end{tabular}

5) Certificates under diploma

Diploma
a. Bachelor
High diploma
b. Master
Ph.D.

6) General and sub-specialty

7) Did you get lessons in financial analysis and its relationship to banks performance yes no

\section{Second: questionnaire axis}

Put mark in the field that it deems appropriate for your answer

\begin{tabular}{|c|c|c|c|c|c|}
\hline \multicolumn{2}{|c|}{ A-financial analysis tools } & \multirow[t]{2}{*}{$\begin{array}{l}\text { Strongly agree } \\
\text { agree }\end{array}$} & \multirow[t]{2}{*}{$\begin{array}{l}\text { Not } \\
\text { sure }\end{array}$} & \multirow[t]{2}{*}{$\begin{array}{l}\text { Not } \\
\text { agree }\end{array}$} & \multirow[t]{2}{*}{$\begin{array}{l}\text { Not agree } \\
\text { strongly }\end{array}$} \\
\hline 1 & $\begin{array}{l}\text { Liquidity ratios calculated to measure banks } \\
\text { performance in giving information to take } \\
\text { investment decision. }\end{array}$ & & & & \\
\hline 2 & $\begin{array}{l}\text { Profitability ratios provide information to the } \\
\text { potential investors about the sector and company to } \\
\text { invest in. }\end{array}$ & & & & \\
\hline 3 & $\begin{array}{l}\text { Debt Management Ratios (Capital adequacy ratios) } \\
\text { has become a fundamental pillar in the evaluation of } \\
\text { bank performance under the recommendations of } \\
\text { the Basel } 2 \text {. }\end{array}$ & & & & \\
\hline 4 & $\begin{array}{l}\text { Asset management ratios provided indispensable } \\
\text { information for investment decision in banking } \\
\text { sector. }\end{array}$ & & & & \\
\hline 5 & $\begin{array}{l}\text { The company conducted a basic financial analysis } \\
\text { for all banks operating in the sector. }\end{array}$ & & & & \\
\hline 6 & $\begin{array}{l}\text { There is privacy for the banking sector requires } \\
\text { additional financial analysis. }\end{array}$ & & & & \\
\hline
\end{tabular}




\begin{tabular}{|c|c|c|c|c|}
\hline B- Islamic and traditional banks & $\begin{array}{l}\text { Agree agree } \\
\text { strongly }\end{array}$ & $\begin{array}{l}\text { not } \\
\text { sure }\end{array}$ & $\begin{array}{c}\text { Not } \\
\text { agree }\end{array}$ & $\begin{array}{l}\text { Not agree } \\
\text { strongly }\end{array}$ \\
\hline
\end{tabular}

7 There is privacy for Islamic banks to traditional banks in terms of risk.

8 Islamic banks need liquidity different from traditional banks.

9 Profits take another form in Islamic banks compared to traditional banks.

10 Credit risks are measured by the solvency ratios of capital in traditional banks; do not take the same structure in Islamic banks because of the difference in credit risks.

11 Islamic banks are without interest which is the basis of the traditional banks which requires the observance of this privacy.

12 Islamic banks make business beside of the limited role of credit making it face market risks.

13 Investors in Islamic banks have solidarity and share risks unlike traditional banks.

14 Islamic banks did not face major crises during her lifetime comparing to traditional banks.

\begin{tabular}{llllll}
\hline $\begin{array}{l}\text { C- the suitability of the traditional financial } \\
\text { analysis for Islamic banks }\end{array}$ & $\begin{array}{l}\text { Agree } \\
\text { strongly }\end{array}$ & agree & $\begin{array}{l}\text { Not } \\
\text { sure }\end{array}$ & Not agree & $\begin{array}{l}\text { Not agree } \\
\text { strongly }\end{array}$ \\
\hline
\end{tabular}

15 Do you believe that financial analysis ratios used for Islamic banks can serve the privacy?

16 Is the criterion used for comparison purpose and ratios judge are compatible with Islamic banks privacy?

17 Do Islamic banks need standards for the purpose of results comparison?

18 Do you think as an expert in investment field the analysis of the current rates is not adequate for making investment decisions?

19 Do you think that calculated ratios in the Islamic banks important?

20 Do potential investors get more information than those obtained from financial analysis when made by consultants?

21 Do you think a need for developing specific financial analysis tools for Islamic banks?

22 Do you see that financial analysis tools basic for investment decisions? 
Appendix 2.
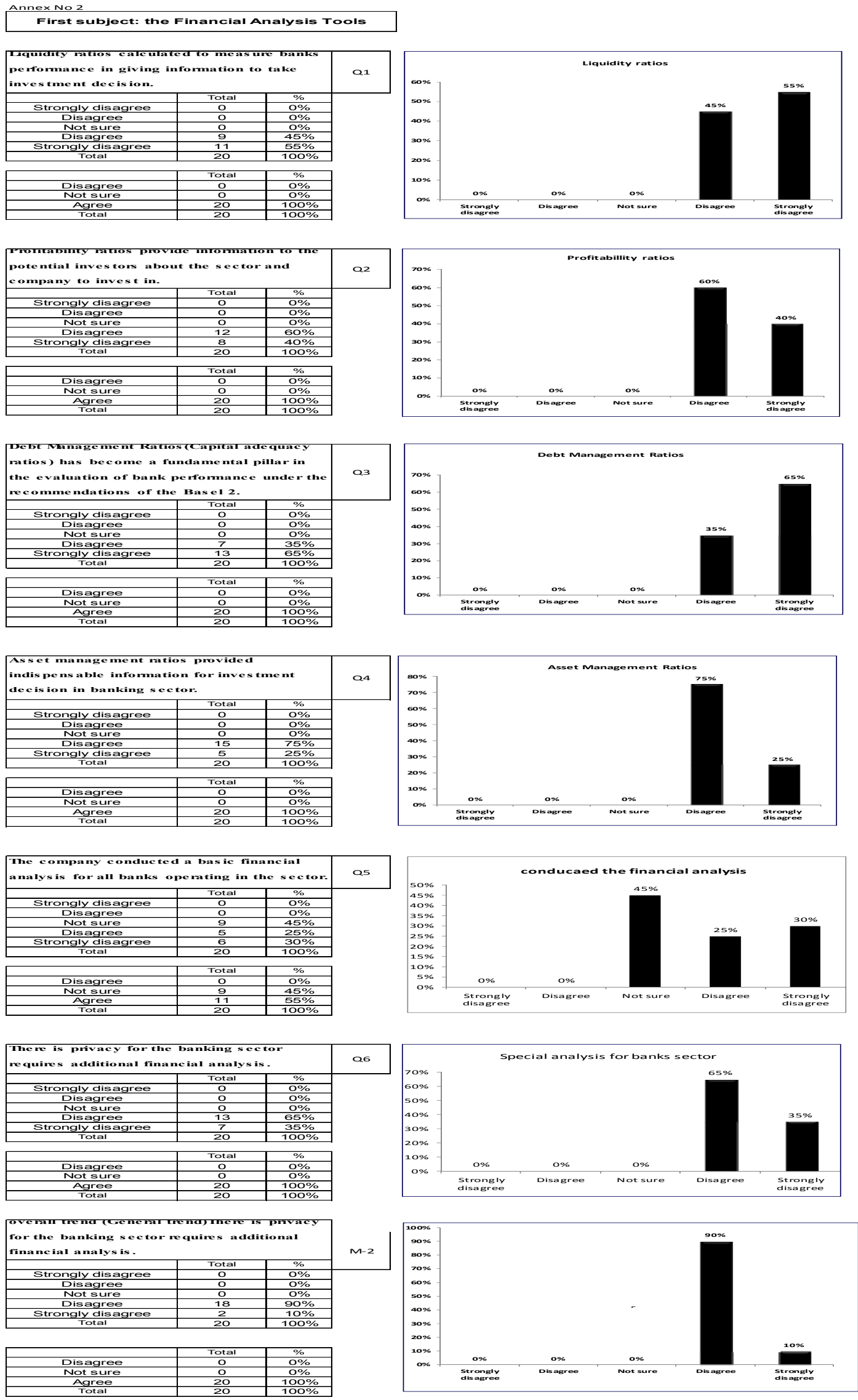
Annex No 3
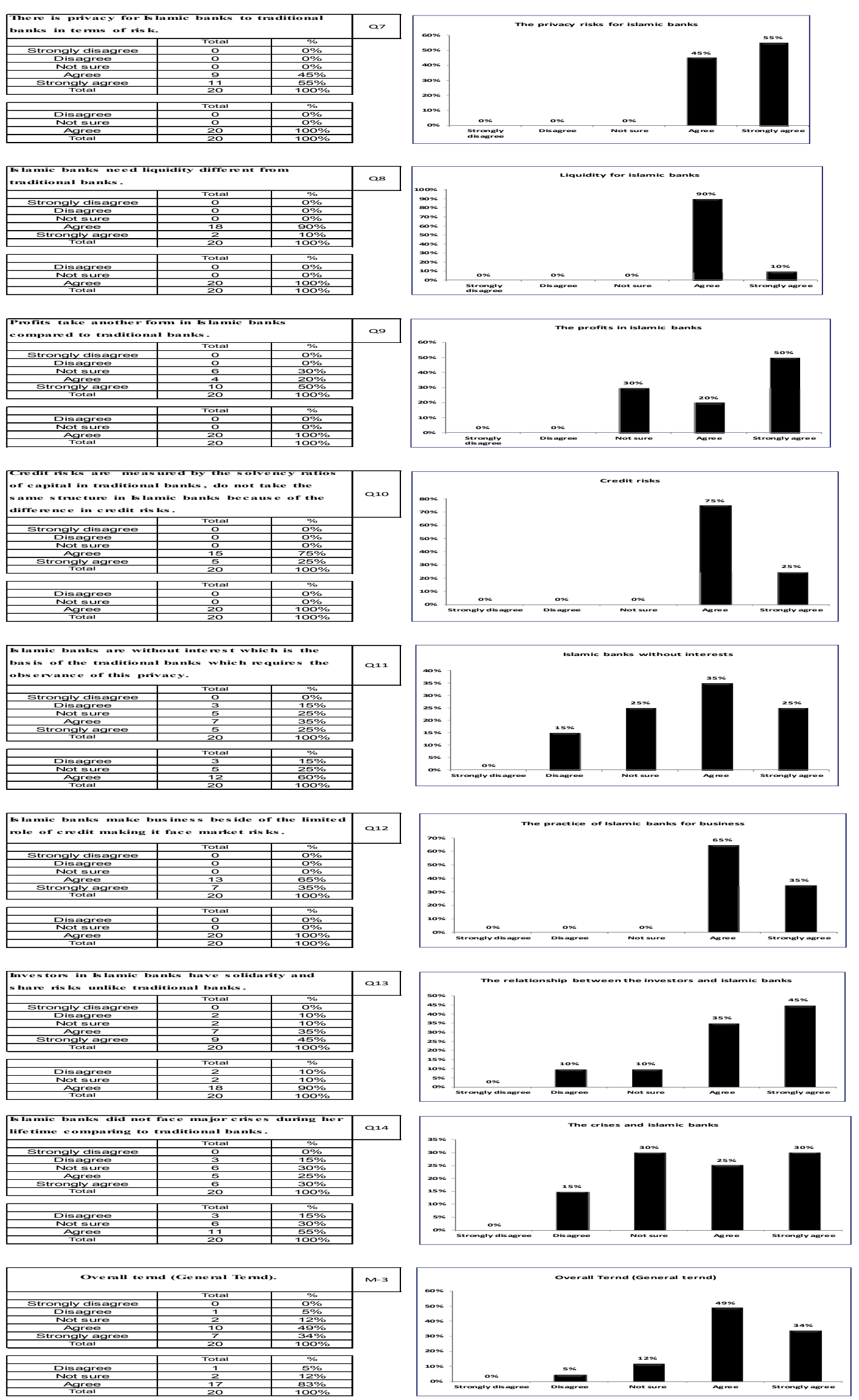


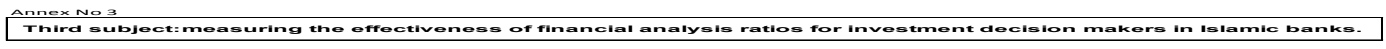
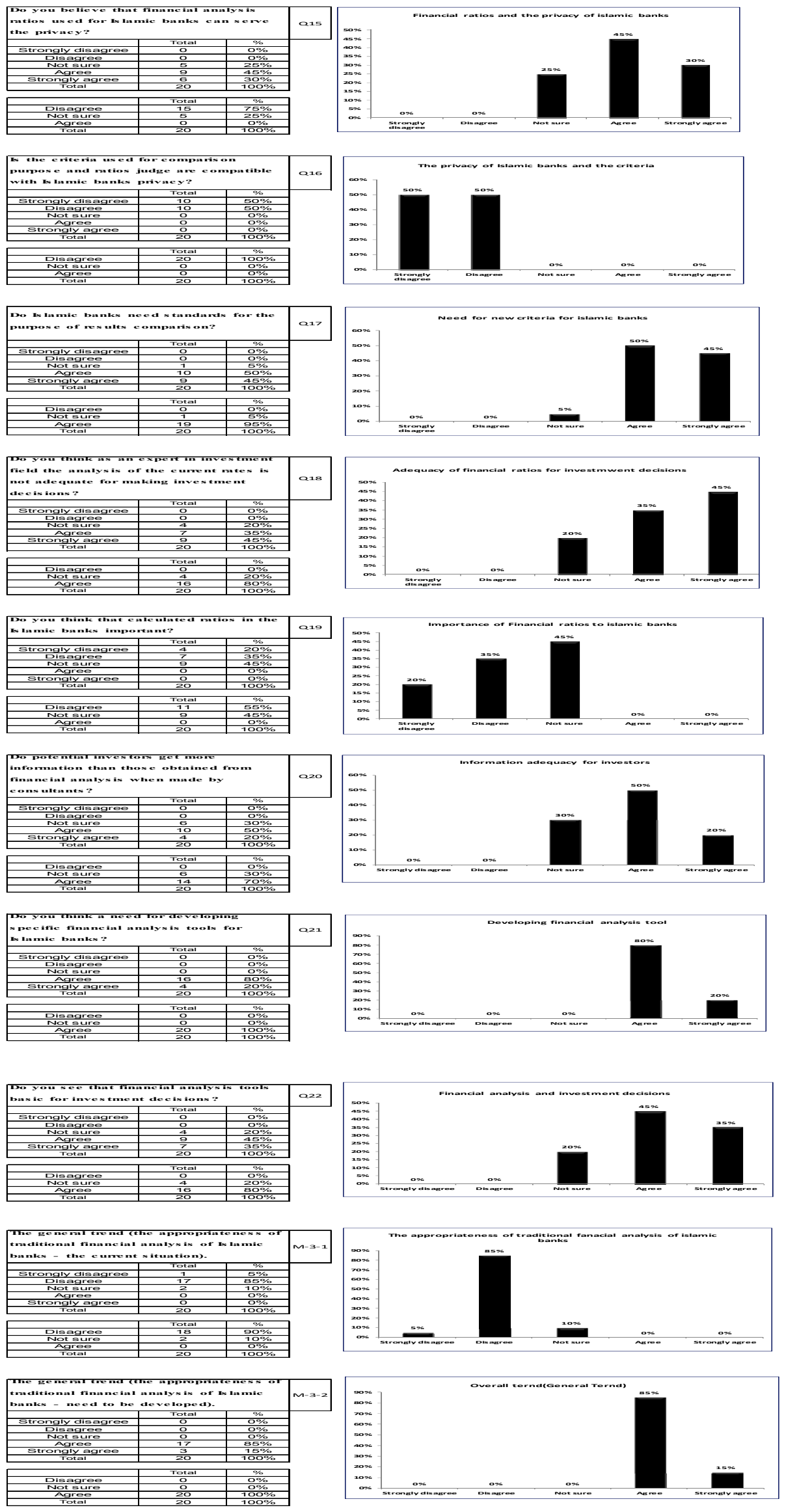


\section{Note}

Note 1. Standard figure "a number or statistical measure was designed with a view to show the change in a variable during a certain period of time". 